\title{
Research on Training Mode of Horse Racing International Talent in Wuhan Business University
}

\author{
Zhuo Sun, Shuang Zhang * \\ Wuhan Business University, Wuhan 430056, Hubei, China
}

Keywords: Wuhan Business University, horse racing international talent, training mode.

\begin{abstract}
Through analysis of the demand conditions of the racing talents at home and abroad, this paper analyses and compares the present situation of talent training between our school and countries with developed horse racing, this paper points out existing problems in the training mode of horse racing in our school and proposes suggestions.
\end{abstract}

\section{Research Background}

\subsection{The development situation of horse racing specialty in Wuhan Business University}

Wuhan Business University started recruiting and training college students of horse racing specialty since 2008, which has already sent more than 1,000 graduates to the horse industry. With the promotion of the international popularity of horse racing specialty in our school, our school has signed a cooperation agreement with the world's top racing group. International equestrian institute signed a strategic cooperation agreement with the world's top horse racing Dali group in November 2015, our school signed an agreement with French horse racing group to jointly build "China-French international equestrian institute" in December 2016.

\subsection{The analysis of horse racing talent demand at home and abroad}

In the United States, Australia, the United Kingdom and other developed countries, horse racing industry is a pillar industry in these countries. There is a great demand for talents in the industry, especially the horse racing industry is a labor-intensive industry, the labor intensity of this industry is relatively high and it has certain risks. In countries with developed horse racing, the horse racing industry urgently needs talent, especially jockey shortage. The horse racing industry is an emerging industry in China, and this industry has a great demand for high-end applied talents who understand management and practice.

\section{The Current Situation and Existing Problems of the International Talent Training Model for Horse Racing in Our School}

2.1 The current situation of the international talent training model for horse racing in our school

The talent training mode is a programmatic document for the school to carry out talent training, guarantee the quality of education and teaching, and realize the goal of talent training. Our school has targeted courses and training programs for all posts of horse racing industry, such as jockey, stable manager and horse racing personnel. Through the cooperation between colleges and enterprise, integrate theory with practice, adhere to combining practice teaching check with vocational qualification certification, and provides the horse racing industry and enterprise with high-quality applied talent who understands both the practice and the theory.

2.2 The existing problems in the international talent training model of the horse racing in our school

2.2.1 The teaching staff, especially the practical training course teachers lack

Because the Wuhan Business University is the first domestic universities to open horse racing specialty in colleges and universities, so the professional teachers of horse racing industry management basically has not studied horse racing knowledge during the period of master and doctor in our school. These teachers have transformed after work, they go to the equestrian club and the horse racing 
company in the holiday to transfer to the horse racing industry. The teachers of theory course better transformed, but the practical training courses, especially the teachers of riding and horse training does not transformed well. There are shortages of professional practical training courses teachers for horse racing in our school; in particular, there are few talents who have both educational background and high riding skills in China.

2.2.2 There are no existing training programs to follow

Wuhan Business University started the recruitment and training of college students of horse racing specialty since 2008, and has recruited students for 10 years. The students' training of horse racing specialty does not have references, the horse racing professional teachers team in our school from the beginning to learn from the opening situation of related specialties foreign horse racing, collect opinions of related leaders of Wuhan city sports bureau and professors in Wuhan colleges and universities, and a talent training program for horse racing is established. However, the talent training program has a gap for the training of international horse racing talents, and the planning, operation and management ability of the international horse racing industry. Therefore, we should adjust the talent training program and explore a scientific and independent training system for horse racing international talent.

2.2.3 Insufficient practical training conditions

Horse racing is called the noble sport, and the special point of this sport is the participation of animals. Horse racing is not a sport like aerobics dancing or track and field and so on, as long as there is one site, you can do sports. The horse racing sport besides the requirements for the ground, the cost of raising and maintaining horses is high. Due to the limitation of ground and school funds, at present, the field of practical training for students of horse racing specialty in our school is small, there are only 13 horses available for teaching due to limited number of small stables., two is a PONY horse among them and cannot be mounted. Most of the practical training courses for horse racing and equestrian students in our school are carried out in the horse field, and the insufficient practical training conditions are not conducive to the improvement of students' professional practical training skills.

2.2.4 Serious lag in teaching materials construction

Because horse racing is an emerging specialty and discipline in China's universities, the domestic books on horse racing are blank. The division of labor of the horse racing specialties teachers is clear, and each teacher has written teaching materials to in his own specialized area. With the accumulation of school experience and deepening of research, the teachers in our school have written six monographs on horse racing specialty, including "horse care". There are totally 15 courses in professional foundation and core course of horse racing specialty students, especially the most core courses; the equestrian monograph has not yet been published. Therefore, it is still a long way to perfect horse racing monograph and teaching materials, write for international and suitable textbook for present situation of the development of horse racing industry in China

\section{Analysis of Talent Training Mode in Foreign Countries with Developed Horse Racing Industry}

\subsection{British BHS system analysis}

BHS certification is a set of scientific and systematic training and examination developed by BHS (British Horse Society), in order to ensure the professionalism, the standardization and systematization of the staff of the horse industry, according to the horse industry personnel certification system. This system has the world's top education concept, operation management technology and certification qualification of professional practitioners, this system has five grades, the examinee must take the examination from first level, each level has a test point in horse care, especially the riding. It not only helps practitioners to better grasp the horse knowledge, nursing, riding technology and teaching skills, assist and guide the horse industry institutions to strengthen their own level, promote the overall level of the industry. 


\subsection{French Gallop system analysis}

The France Gallop system is most mature and successful one in the global horse industry certification system. The system has 7 levels totally, and can get level 3 in China currently. The examination characteristics of this system are must be taught and assessed by the French Equestrian Association, so the standards around the world are more uniform. French Gallop system are vivid, it is more suitable for the equestrian club to carry out promotion and training of pony teaching, at the same time, it has a better reference index for equestrian enthusiasts to improve skills, business promotion is good.

\subsection{German FN system analysis}

Germany is a horse racing and equestrian power, and this country ranks first in Olympic equestrian events. The FN system has a proud athletic performance, and it is well known in the world. This system has totally 10 levels, and can get 4 levels in China; the system has poor recognition and promotion in our country. This system has a high value, and the examiners sent from Germany have high level, including Olympic riders. The examination is more difficult, and each level of examination must pass the level of dance test before the obstacle can be tested. The high difficulty is also the reason why the system is not well promoted.

\section{Construction and Suggestion of the International Talent Training Model for Horse Racing in Our School}

\subsection{Establish reasonable and scientific training standard}

With the acceleration of the world economic integration process, there are more and more exchanges among the horse industry, and the integration of the horse industry is getting higher and higher. The trained horse racing talents in our school should be integrated into the world horse industry to meet the requirements of internationalization. We must change the previous training mode, pay attention to training international horse racing talent, who are familiar with the present situation of China's horse industry, the traditional culture of the horse industry, have a good foreign language level, solid horse riding skills, the international consciousness, cooperation spirit, innovation ability and the honesty, and conform to the international professional qualification standards of the workforce. The change of the training standard is not only limited to oral and written language, but also changes in training standards, training methods, and means and training ideas.

\subsection{Build an influential international horse racing teacher team}

The teachers' team is an important basis for the internationalization degree of specialty, and it is also an important criterion to evaluate the internationalization degree of education and teaching in a school. In order to develop and improve one specialty, it is necessary to train a large number of high-quality horse racing international talents, we must first build an excellent horse racing teachers' team. The construction of horse racing teachers should be based on the principle of bringing in and going out, we should encourage and support local professional teachers to study and improve at the overseas horse racing elite schools. At the same time, preferential policies are made to introduce foreign horse racing professional teachers. Only in this way, the students' professional knowledge can act on international convention, understand and master the principles and practices of international horse racing.

\subsection{Improve the practical training conditions and strengthen the cooperation of school and enterprise, jointly train the international talents of horse racing}

From the current situation of talent demand of horse racing industry both at home and abroad, the high skilled training talents are urgent needed. Therefore, we should train talents in accordance with the demand of the market, and improve the practical training ability of the talents. In the past, due to the limited training conditions in our school, the students strengthen their theoretical learning in school, and let students learn practical skills in horse racing clubs through school and enterprise cooperation. At present, in order to host the eighth Military World Games, Wuhan has invested one hundred and twenty million in our school to build an international standard equestrian ground. This will greatly improve the practical training conditions of the horse racing and equestrian students in our school, and 
improve the training skills of the students. At the same time, the cooperation school and enterprise cannot be relaxed, we should select excellent students to transport them to professional horse racing clubs, and train them to be excellent college riders.

\subsection{Attach importance to the construction of course system and strengthen the construction of teaching materials.}

In order to better train the international talent of horse racing, we need to absorb and draw lessons from or the teaching methods and contents with international vision and intercultural content. At the same time, vigorously strengthen setting of horse racing international course, put the view on the international horse industry, we can draw lessons from or revise original English teaching materials, let the students really learn useful content in the class, rather than deal with an exam. Strive to promote and improve the construction of professional teaching materials of horse racing, encourage the practical training teachers to publish the teaching materials on horse riding and horse training at an early date, so that each specialized course has corresponding teaching materials to be taught.

\section{Acknowledgements}

Wuhan Municipal Universities Teaching Research Project(Research on the Training Mode of Horse Racing International Talent in Wuhan Business University).

Project number: 2017101.

\section{References}

[1]. Li Qingling, Lv Yaozhong: Talent Training Strategy under the Background of Internationalization of Higher Education, China Higher Education, No.Z1, 2010.

[2]. Wang Hengan, Huang Jingzhong. The Research On Reform Of Talent Training Mode In Higher Normal Universities [J], Data of Culture and Education, 2009 (21).

[3]. Tian Changlin. China's Higher Education Reform from the Trend of Higher Education in the United States[J], Journal of Higher Education, 1986 (02). 